\title{
頭蓋内に進展した副咽頭腔舌下神経鞘腫例
}

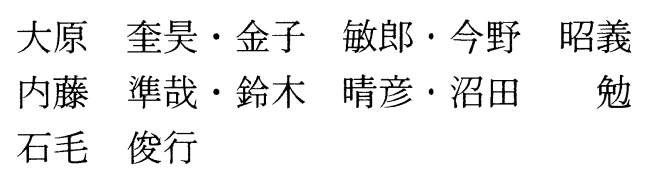

\section{A Case of Intra- and Extra- Cranial Hypoglossal Neurinoma}

\author{
Kuho Ohara, Toshio Kaneko, Akiyoshi Konno, \\ Junya Naito, Haruhiko Suzuki, Tsutomu Numata \\ and Toshiyuki Ishige \\ (Chiba University)
}

A 51-year-old male with a history of palsy and atrophy of the right side of the tongue was admitted to our clinic in April, 1991. General physical examination revealed nothing remarkable, and no café au lait spots were found. Ultrasound examinations delineated the size and boundary of the neck mass and its relationship to the great vessels. MRI in short spin echo revealed a low density tumor mass. A 3-dimension CT scan showed destruction and enlargement of the jugular foramen and hypoglossal canal. CAG demonstrated a hypovascular mass and no tumor stain. A biopsy was performed via the oral cavity, and the histopathological report was Antoni type B neurinoma, without malignancy.

On July 1991, mastoidectomy and suboccipital craniotomy were performed with a staged extracervical approach. The 10th and 11th cranial nerves were intact, but the 12th nerve was involved in a massive cystic tumor which extended intracranially through the enlarged jugular foramen and hypoglossal canal of the skull base. The extracranial 9th nerve was cut because it was involved in the neck mass. Intracranial hypoglossal neurinoma is a rare lesion, and its dumbbell-like extension to the neck is even more rare.

The best treatment of this tumor is total removal. However when it is strongly adherent to the medulla, subtotal removal is essential because of the risk of brain damage, since this tumor is benign.

Key words: dumbbell-like hypoglossal neurinoma, ultrasound examinations, 3-dimension CT

はじめに

今回我々は極めて稀とされている頭蓋内・外 にまたがる舌下神経鞘腫の一例を経験したので, その診断と治療について若干の文献的考察を加 えここに報告する.
症 例
患者 : 51 歳, 男性,
主訴 : 舌右半側の麻㽻と萎縮.
家族歴・既往歴 : 特記事項なし.
現病歴 : 中学生の頃より風邪をひくと右の扁 
桃腺がよく腫れ，近医より処方された内服薬で 軽快していた。約 4 年前 (昭和62年) 頃家族や友 人ょり言語のもつれを指摘され，鏡で舌をみて 主訴に気付くも放置していた。

平成 3 年 1 月頃より言語のもつれがひどくな ったため家族に強く勧められ，平成 3 年 4 月 5 日当科を受診した。

初診時現症：全身状態は良好，意識清明であ り皮膚所見に異常はなかった。血液，尿，生化 学的検查は正常範囲内であった。 めまいや嗄声, Horner 症候もなかった。言語は「ら」行でや や不明瞭ながらも充分判別できた。

図 1 は初診時の舌所見である. 舌右半側飞萎 縮と麻痖がみられ，突出時同側への偏位々攣縮 がみられた。右軟口蓋が軽度に膨隆していたが， 粘膜面に潰瘍や発赤などはなかった。右耳下部 に径約 $4 \mathrm{~cm}$ の弾性硬の腫瘤を触知し, 左右に 可動性があり， 口腔内の膨隆と連動していた。

検査所見：頸部超音波断層像（図 2 )では，舌 根部に接する，境界が比較的明瞭で内部ェュー ほぼ均一な腫瘤がみられた。 MRI(T1 強調) 像 (図 3 )では，頸部より後頭蓋内へと進展する亜 鈴状で低信号の腫瘍がみられ，T2強調にて高 信号を呈していた。大血管群との関係をみるた め超音波カラードップラー検査を施行した (図 4 ). 頸部の腫瘍により内・外頸動脈は外側 に圧排され，内頸動脈の一部は腫瘍に包まれて

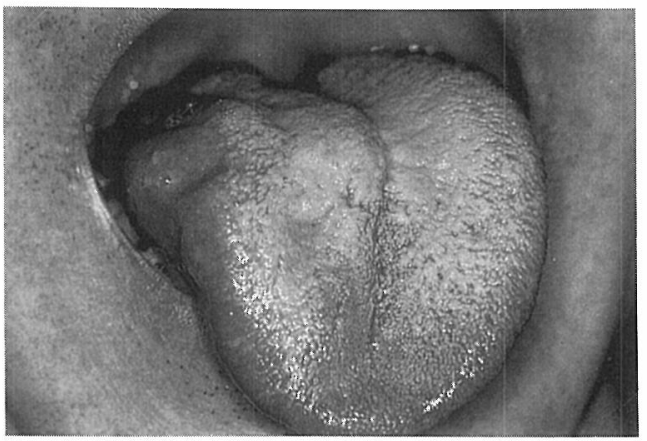

図 1 初診時舌所見 舌右半側に麻痺と萎縮がみられる。
いた。CAG（頸動脈造影）(図 5 )では, 内頸動 脈は壁がやや不整で腫瘍により前外方に圧排さ れていたが，腫瘍濃染は確認されなかった。頭 蓋骨との関係を知るため 3 次元 CT(図 6 )を施 行した。舌下神経管特よび頸静脈孔に腫瘍によ ると思われる破壊と桩大がみられた。

以上の問診，視・触診ならびに画像診断より

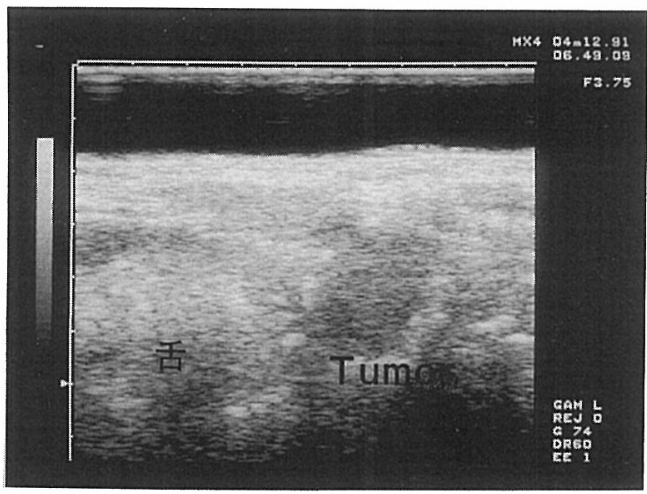

図 2 頸部超音波断層像

腫瘍は舌根部に接し境界は比較的明瞭で 内部ェコーは泀ぼ均一である。

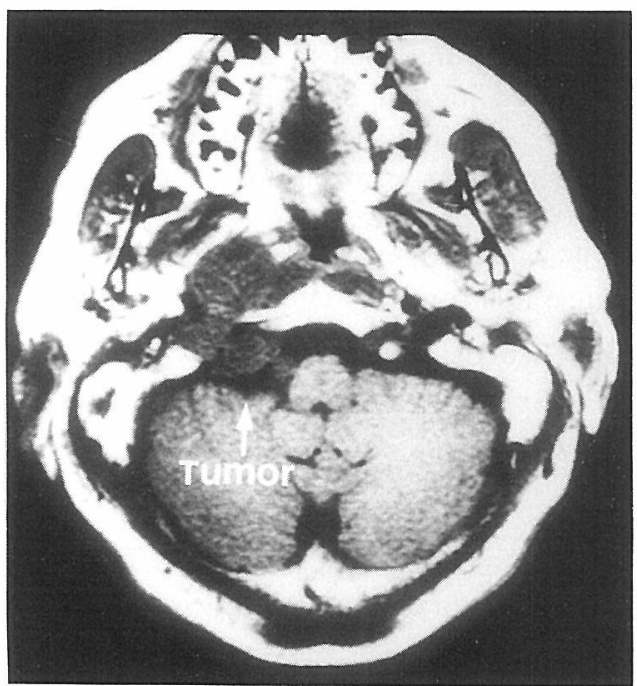

図 3 術前の $\mathrm{MRI}$ (T1 強調) 像 腫瘍 (矢印) は，低信号，亜鉿状で頸部より 後頭蓋内へと進展している. 
良性の神経性腫瘍もしくは多形腺腫を疑ったが， 確定診断のため口腔内より生検を行った結果, 神経鞘腫であった。

脳神経外科との combined operationをする ため平成 3 年 6 月 25 日当科入入院し， 7 月 2 日 経口挿管による全身麻酔にてまず頸部腫瘍の摘

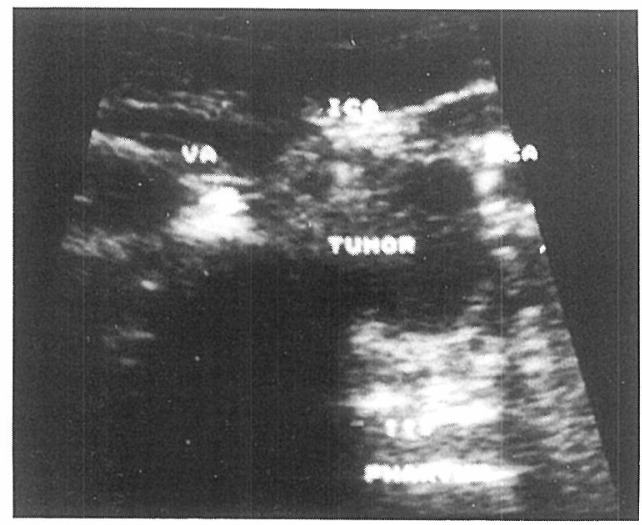

図４超音波カラードップラー像 腫瘍により内・外頸動脈は外側に圧排され， 内頸動脈の一部は腫瘍に包まれていた。

ICA : 内頸動脈 ECA : 外頸動脈 VA：椎骨動脈

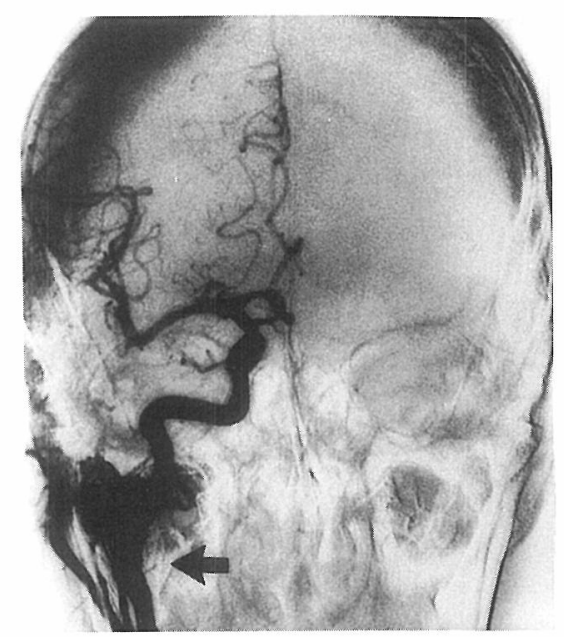

図 $5 \mathrm{CAG}$ (頸動脈造影) 像 内頸動脈は矢印の部位にて，壁がやや不整で 腫瘍により前外方に圧排されていたが，腫瘍 濃染は確認されなかった。
出術を施行した。

皮膺切開は耳下腺腫瘍に準じ，S 字切開法を 用い乳様突起部へ補助切開をいれた。

定型的に顔面神経幹を露出し耳下腺を前方に 下顎骨とともに压排し，顎二腹筋，茎突舌骨筋 などの筋群を切離すると表面平滑で黄色の被膜 をるつ腫瘍が露出した。内頸静脈は腫瘍により 外側に圧排され紐状であった。内頸動脈はその 分岐部より頭蓋底へ向けて約 $3 \sim 4 \mathrm{~cm}$ にわた り腫瘍に取り巻かれていた。分岐部にて腫痬の 被膜に縦切開をくわ穴，黄色ゼリ一状の内容物 を被膜内で吸引し，腫瘍内の容量を減量した。 内頸動脈からの被膜の剝離は容易であった。

さらに視野を広くするため乳様突起の下端を 削開，茎状突起を鈷除し，S 状静脈々顔面神経 管垂直部の一部を露出させた。 内頸静脈を $\mathrm{S}$ 状 静脈への移行部にて結紮切断すると頭蓋底を明 視下に持くことができた。ささらに腫瘍の剝離を 頭蓋底へとすすめ，破壊桩大された頸静脈孔な らびに舌下神経管の高さにて頸部の腫瘍を結禁 摘出した(図 7 ).

舌咽神経は腫瘍の後下側方で一部腫瘍に巻き

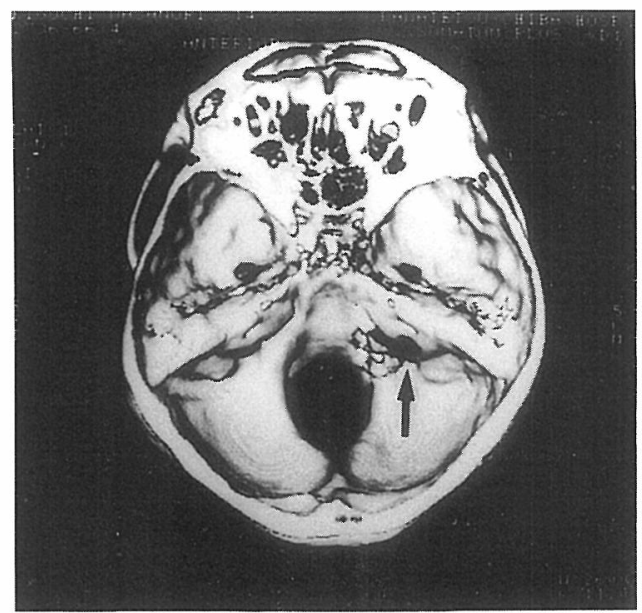

図 63 次元 $\mathrm{CT}$ 像

頸静脈孔，舌下神経管に腫瘍に上ると思われる 破壞と拡大がみられる. 
込まれていたため同部位にて切断した。迷走神 経は腫瘍の後方で一部に癒着がみられたのでそ

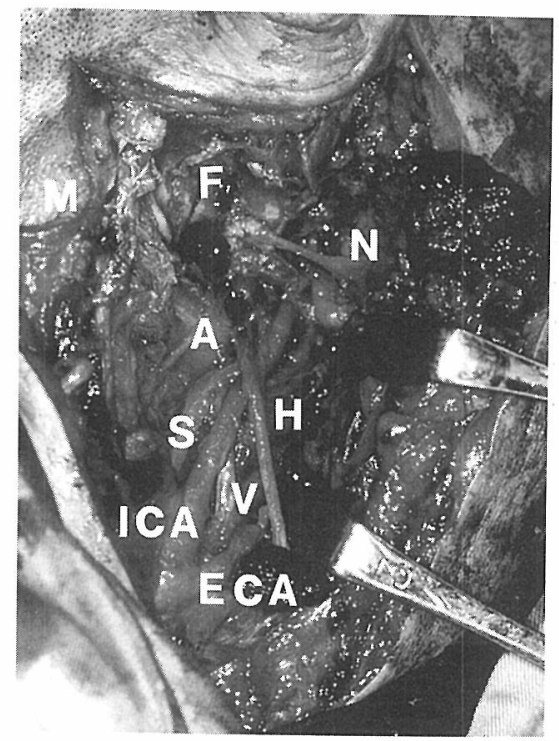

図 7 耳鼻咽喉科の術中写真

腫瘍を頭蓋底にて結紮摘出したところ。

A : 環椎の横突起

$\mathrm{F}$ : 頸静脈孔・舌下神経管

$M$ : 乳突洞 $S$ : 交感神経幹

ICA : 内頸動脈 ECA : 外頸動脈

$\mathrm{N}$ : 顔面神経 $\mathrm{H}$ : 舌下神経

$\mathrm{V}:$ 迷走神経

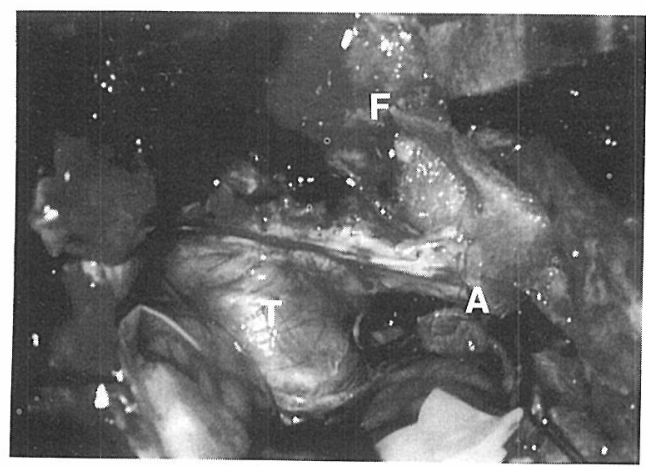

図 8 脳神経外科の術中写真

頸静脈孔・舌下神経管 $(\mathrm{F})$ 上り腫瘍 $(\mathrm{T})$ を引き抜 いたところで，この下で舌咽・迷走神経が容易に 剝離し得た。

A：副神経
の部位で神経の表層を切除した．舌下神経は頭 蓋底付近にて腫瘍に入り込んでいたため切断し た。交感神経幹と副神経は腫瘍との瘉着はみら れず容易に剝離し得た。

頭蓋内の腫瘍に対しては 2 週間後当院脳神経 外科にて後頭下開頭法で摘出術を施行した。

後頭骨を削開し，硬膜に切開を入れ S 状静脈 を高位にて結紮すると腫瘍の被膜が露出できた。 図 8 は腫瘍を挙上したところで，破壊拡大した 頸静脈孔・舌下神経管が見党る。

CUSA にて内容物を吸引し，小脳と舌咽・ 迷走・副神経より被膜を剥離摘出した。剝離は 容易であった．舌下神経は確認同定できなかっ た。硬膜の欠損は大腿筋膜にて補った。

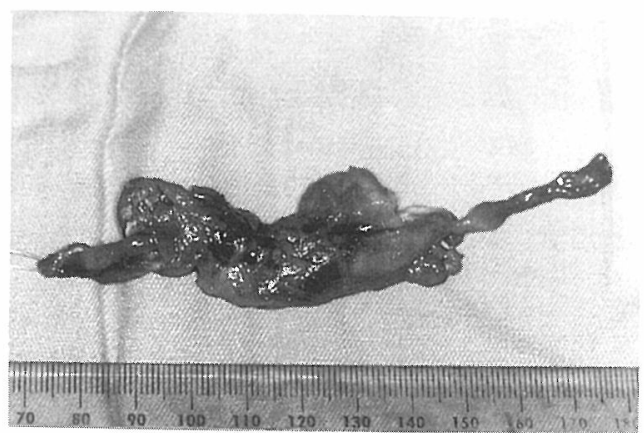

図 9 頸部腫瘍の摘出標本

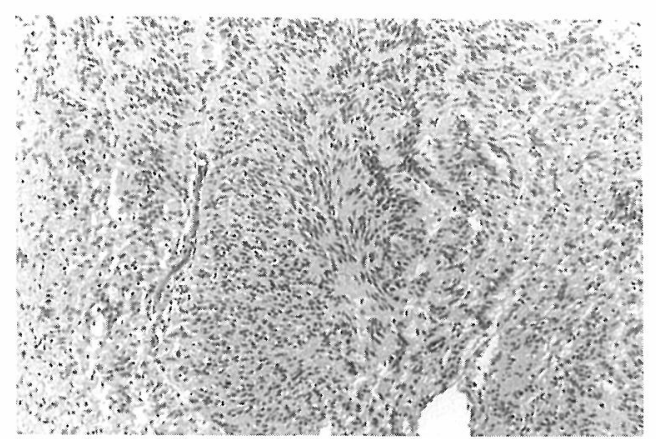

図10 病理組織像 $(\mathrm{HE} \times 100)$

腫瘍細胞は紡錘形を呈し, palisading pattern, Verocay bodies, Antoni B型の細胞がみられ，異 型性なく神経鞘腫の所見である. 
頸部腫瘍の摘出標本(図 9) は長径約 $7 \mathrm{~cm}$ で あり, 頭蓋内腫瘍は直径約 $4 \mathrm{~cm}$ であった。

病理組織学的所見(図10): 腫瘍細胞は紡錘形 を呈し一部に核の palisading pattern が見られ， 中央にはVerocay bodiesを認め, その右方に はAntoni B型の細胞が見られた。腫瘍細胞に 異型性はなく神経鞘腫の所見であった。

以上の臨床所見，手術所見ならびに病理組織 学的所見より, 本腫瘍を舌下神経由来の神経鞘 腫と診断した。

術後約 3 力月の $\operatorname{MRI}(\mathrm{T} 1$ 強調) 像にて(図11) 明確な腫瘍の残存はみられていない。顔面神経 麻痺は軽快しつつあるも, 脱落症状として舌咽 ・迷走・舌下神経麻㽻が残った. 今後も十分な 経過観察を要すると思われる。

\section{考察}

神経鞘腫あるいは神経線維腫はSchwann 細

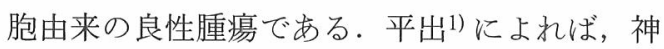
経鞘腫と神経線維腫との鑑別には病理学的に多 くの問題があり，明確な分類は困難であるが， 一般に神経鞘腫は被膜で覆われており, 孤立性 であるのに対して, 神経線維腫は被膜を欠き, 多発性であるとしている。

神経鞘腫は神経の存在部位ならばどこにでも 発生しうるが, Putney ら ${ }^{2)}$, Gupta ら ${ }^{3)}$, Daly

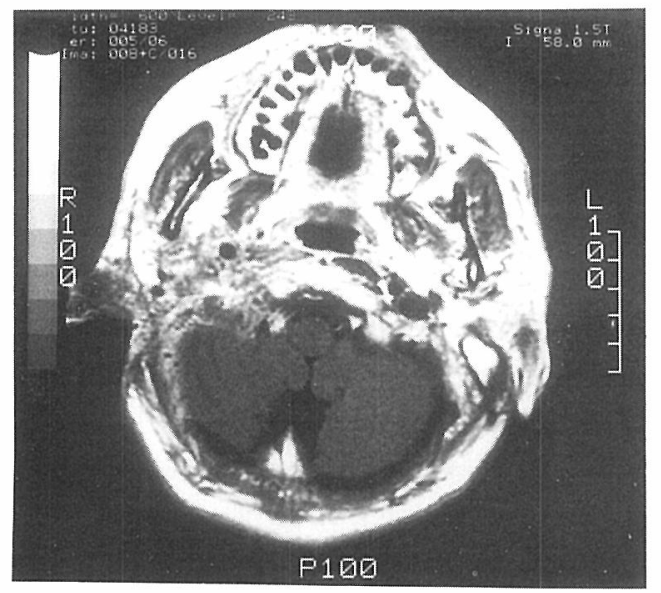

図11 術後 3 カ月の MRI ( $\mathrm{T} 1$ 強調) 像 明確な腫瘍の残存はみられていない。
ら4にによれば軀幹よりは頭頸部領域に多く，全 神経鞘腫のらち25〜 40\%を占め, 頭部では聴神 経腫瘍として内耳道扣よびその近傍に多く, 頸 部では側頭部領域特に副咽頭腔, 頸静脈孔付近 が好発部位であると述べている。

聴神経以外では三叉神経, 迷走神経, 舌咽神 経, 副神経, 舌下神経などにもみられるが，か なり稀である5)6).

神経鞘腫は资髄の背側根や, 知覚成分のみか ら成る脳神経に発生することが多く，混合神経 に発生したものでもとの知覚成分より発生する ことが多い、7)。

舌下神経は延骾の全長にわたって存在する舌 下神経核から出て，舌運動をつかさどる純粋な 運動神経であり ${ }^{8)}$, この純粋な運動神経から成 る舌下神経から神経鞘腫が発生することは極め て稀である5)6)。

田村ら ${ }^{6)}$ は頭蓋内神経鞘腫の発生頻度につい て316例を調べ，聴神経303例(95.9\%)，三叉神 経 7 例 $(2.2 \%)$, 頸静脈孔部 4 例 $(1.3 \%)$, 舌下 神経は 2 例 $(0.6 \%)$ のみであったと報告してい る.

頭蓋内に発生した舌下神経鞘腫の文献的報告 例は, 野々村ら 9) や山口ら ${ }^{10)}$ によれば40余例で あり,このらち亜鈴状に頭蓋外へも進展した症 例は 9 例にすぎない9) と報告している.

臨床症状としては腫瘍の起源である舌下神経 の麻瘏症状が最も特徵的であるが, 神経鞘腫そ のものは無痛性腫瘤であり, 多くの場合は長年 にわたり患者に気付かれず放置され，発見が遅 れる11).

頸部に発生したものではまず頸部腫瘤を自覚 して受診するが，頸部の好発部位である副咽頭 腔は先の中に内・外頸動脈や内頸静脈, 舌咽 · 迷走・副・舌下神経などの脳神経,ならびに交 感神経幹, リンパ節, 脂肪組織などを入れ，上 下四方をそれぞれ頭蓋底，下顎骨，筋群などに より囲まれているため，初診時にはかなり腫瘍 が大きくなっている場合が多い。

本症例でも家族や友人より言語のもつれを指 
摘され鏡で舌の萎縮に気付くも受診までに約 4 年を要し，その間頸部の腫瘤にはまったく気付 かなかった。

頭蓋内腫瘍が増大すればその mass effect に より種々の症状が出現する。骨迶膜圧迫刺激によ る後頭部から後頸部痛や吐き気, 脳幹部圧迫に よる longtract sign としての運動・知覚麻痺症 状などを呈する10).

舌下神経麻痖が本症の最も有力な診断根拠で

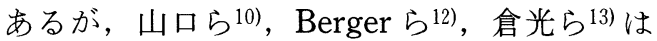
舌下神経麻痺を欠いた症例を報告している。そ れは本腫瘍の発生部位に関係する. 太田ら ${ }^{8)}$ に よれば舌下神経は10〜15本の rootlets（細根）を なして延髄を出るが，舌下神経管を出ると 1 本 の神経となる．頭蓋内の何本かの rootletsより 腫瘍が発生したとしても圧迫や浸潤がなければ 残された他の rootlets は機能が温存され, 腫瘍 の存在にもかかわらず，何ら欠損症状を呈さな い10)ことになる.

Keye ら ${ }^{14)}$ は頸静脈孔神経鞘腫の発育様式に ついて，(A)主として頭蓋内発育，(B)骨内に発 育・進展, (C)主として頭蓋外に進展, の 3 型に 分類している.

舌下神経麻痺症状を呈さなかった上述の 3 例 はこのらちのA型に相当すると思われた。

本症例の場合は, 頭蓋内圧亢進症状はなく, 舌下神経麻痺以外の脳神経症状もなかった。 た，耳下部に腫瘤が存在するものの自覚症状と してはなく, MRIや 3 次元 CT などの画像上 頸静脈孔・舌下神経管に破壊と拡大がみられ， Keye らのB型に相当すると考兄られた.

本腫瘍の診断に際して, 頭蓋内の検索は脳神 経外科領域の諸検査すなわち頭蓋断層撮影,

Stenvers 法, axial-coronal CT, reconstruction-sagittal CT, metrizamide-myelography, CT-cisternography, MRI などが有力である13).

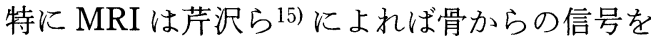
検出しないため, CT ではアーチファクトの多 い後頭蓋窩においても明瞭に mass を検出でき， 管に腫瘍が限局する例や側頭骨内への進展例に
も有効であるとしている.

舌下神経管はその左右差所見が重要であり， 聴神経腫瘍と同様に $2 \mathrm{~mm}$ 以上の差は有意であ るとしている1213). 頸静脈孔近傍・副咽頭腔で はさらに超音波断層検査, 超音波カラードップ ラー検査, sialo-CT, CAG, DSA などの血管造 影が参考となる16).

画像診断のみで組織学的診断までつけること は未だ困難であり，確定診断には組織学的検索 に拠らねばならない，術前の生検に関して，腫 瘍細胞の散布や大血管の損傷の可能性があるた め必ずしも必要はないとする意見1718)19）や悪性 が疑われる場合のみに行われるべきである15)20) とする意見があり一定の見解はない．

本症例は頭蓋内への進展例であり，組織像に よって治療方針が大きく異なる場合があるため， 口腔内より生検を行い有力な情報を得ることが できた。

治療は基本的には外科的に摘出するしかない。 放置しておくと必ず増大し，好発部位である頸 静脈孔近傍・副咽頭腔には大血管や重要な神経 が存在するため, 当該神経の脱落症状や圧迫症 状が必ず出現する．放射線療法は無効である11) 手術の時期が遅きに過ぎれば重篤な脳幹症状, とくに呼吸不全をきたしやすく，そのため術前 に予防的気管切開の必要性を強調する意見もあ る2122). 現在でも術後の呼吸管理には充分注意 が必要であることは論を待たないが，近年顕微 鏡下手術の普及扣よび麻酔や術後管理の進歩に 伴い必ずしも気管切開は必要ではないと考学る。

頭蓋内の腫瘍に対するアプローチ法としては 発生部位により多少の差異はあるようであるが、 後頭下開頭法が一般的である ${ }^{23) 24)}$. 頸部への到 達法は腫瘍の進展範囲や進展方向によって異な るが，広い視野を得るためには頸部外切開法が 基本となる. 脳神経外科との combined operation に際して一期的手術，二期的手術のいずれ を用いるかに関しては未だ一定の見解はない， Jackson ら ${ }^{25)}$ は，手術時間が16〜18時間以内で 同一術野かその延長にて頭蓋内・外の腫瘍が明 
視可能な場合は一期的，それ以外の場合や頭蓋 内腫瘍が直径 $4 \sim 5 \mathrm{~cm}$ 以上の場合は二期的手 術を勧めている。

本症例の場合は時間の都合と頭蓋内腫瘍の大 きさの観点から二期的手術とし，気管切開術も 行わずにすんだ.

頭蓋内に拈いて腫瘍が脳実質や脳幹と強く癒 着する場合は, 本腫瘍が元来良性であり CT や MRI にて確実に経過観察が可能であることを 考慮すれば無理に全摘する必要はなく，同部位 は被膜内摘出で充分である1013126).

本症例の場合は頭蓋内腫瘍と小脳との瘉着は 軽度で剝離は容易であった．頸部の腫瘍へのア プローチは乳突部への補助切開を併用した耳下 腺腫瘍の $\mathrm{S}$ 字切開法を用い, 乳様突起部を削開 し顔面神経幹垂直部ならびに $\mathrm{S}$ 状静脈の一部を 露出させることによって視野を広くとることが でき，頭蓋底を明視下に拈き腫瘍を全摘するこ とが可能であった.

本腫瘍の予後は極めて良好であり, 摘出が完 全であれば再発はない。

\section{まとめ}

1. 51歳, 男性で舌右半側麻痺と萎縮を主訴 とした頭蓋内・外に亜鈴状に進展する舌下神経 鞘腫の一症例を経験したので，その診断，治療 に関し若干の文献的考察を加光報告した.

2 . 舌下神経鞘腫の診断には CT, MRI が有 用であり，特に頭蓋骨との関係を調べるには 3 次元 CT が有効であった。

3. 頸部の腫瘍に対しては，その拈拈よその 拡がりと血管群との関係を知るため, 触診, 視 診に引き続き, 超音波断層検查, 超音波カラー ドップラー検査が有用であった。

4. 治療は脳神経外科との combined operation にて外科的に全摘することが最良であるが， 脳膜や脳幹部との癒着が強い症例では被膜内摘 出にとどめ，無理に全摘する必要はない。

本論文の要旨は, 第33回日耳鼻千葉県地方部会学 術講演会にて口演した。
尚, 手術所見を提供して頂いた当大学脳神経外科 学教室に対し感謝の意を表します。

\section{参考文献}

1) 平出文久: 神経系腫瘍. 耳喉 $55: 881 \sim 886$, 1983.

2) Putney FJ, Moran JJ and Thomas GK : Neurogenic tumors of the head and neck. Laryngoscope $74:$ 1037 1059, 1964.

3) Gupta TK, Brasfield RD, Strong EW, et al : Benign solitary schwannomas (neurilemmomas). Cancer $24: 355 \sim 366,1969$.

4) Daly JF and Roesler HK : Neurilemmoma of the cervical sympathetic chain. Arch Otolaryngol $77: 262 \sim 267,1963$.

5）城山雄二郎, 阿美古征生, 青木秀夫, 他 : 頸静 脈孔近傍神経鞘腫の 4 例. 脳外 $16: 313 \sim 319$, 1988.

6) 田村 晃, 塚本 泰, 斎藤 勇, 他: 舌下神経 鞘腫の 2 例. 臨床神経 $11: 773,1971$.

7) 武川昭男 : 神経線維腫・神経䩗腫. 耳喉 49: 777 786, 1977.

8）太田富雄, 西村周郎：脳神経外科学. 56頁, 金 芳堂, 京都, 1979 .

9）野々村光栄, 福島英行, 平野滋, 他: 後頭下 開頭を要した副咽頭腔舌下神経鞘腫. 第15回日 本頭頸部腫瘍学会予稿集. 182頁, 1991.

10）山口文雄, 高橋 弘, 岡田卓郎, 他: 小脳症状 にて発症した頭蓋内舌下神経鞘腫の一例. 脳外 18:963 967, 1990.

11）佐藤公輝，末永 通，田中克彦：頭頸部神経䩗 腫の18例. 耳鼻 $33:$ 943 946, 1987.

12) Berger MS, Edwards MB and Bingham WG : Hypoglossal neurilemmoma; case report and review of the literature. Neurosurgery 10 : 617 620, 1982.

13）倉光 徹, 清木義勝, 柴田家門, 他 : 頭蓋内舌 下神経鞘腫の 1 例. 脳外 $14: 1463 \sim 1469,1986$.

14) Keye AH, Hahn JF, Kinney SE, et al : Jugularforamen schwannomas. J Neurosurg $60: 1045$ $\sim 1053,1984$.

15）芹沢 徹, 山浦 晶, 大里克信, 他 : 舌下神経 鞘腫の 1 例. 脳外 $17: 279 \sim 283,1989$.

16）大原奎吴, 金子敏郎，今野昭義, 他：副咽頭腔 畽瘍15例の臨床的検討 一教室11年間の統計一. 
口咽科 $4: 77 \sim 86,1992$.

17) Heeneman $\mathrm{H}$ and Maran AGD : Parapharyngeal space tumors. Clin Otolaryngol $4: 57 \sim 66$, 1979.

18) Work WP, Hybels RL and Mich AA : A study of tumors of parapharyngeal space. Laryngoscope 84 : 1748 1755, 1974.

19) Som PM, Biller HF and Lawson $W$ : Tumors of the parapharyngeal space, preoperative evaluation, diagnosis and surgical approaches. Ann Otol Rhinol Laryngol 90 Suppl $80: 3 \sim 15,1981$.

20）高岡佳弘, 窪田哲昭, 吉田篤正, 他 : 副咽頭間 隙腫瘍の診断と治療. 日耳鼻 $89: 142 \sim 151$, 1986.

21) Ignelzi RJ and Bucy PC : Intracranial hypoglossal neurofibroma ; case report. J Neurosurg 26 : 352 356, 1967.

22) Bartal AD, Djaldetti MM, Mandel EM, et al : Dumb-bell neurinoma of the hypoglossal nerve. J Neurol Neurosurg Psychiatry 36 : 592 595, 1973.

23）徳川耕一, 阿部 弘, 岩崎喜信, 他 : 大後頭孔 腫瘍. 脳外 $14: 271 \sim 276,1986$.

24) Fish U, Fagan $P$ and Valavanis $A$ : The infratemporal fossa approach for the lateral skull base. Otolaryngol Clin North Am 17 : 513 552, 1984.

25) Jackson CG, Glasscock ME, Mckennan KX, et al : The surgical treatment of skull base tumors with intracranial extension. Otolaryngol Head Neck Surg 96 : 175 185, 1987.

26) 西山正司, 木村 正, 岸本誠司, 他: 脳幹圧迫 を来した舌下神経鞘腫. 耳鼻臨床 $83: 421 \sim 427$, 1990.

\footnotetext{
原稿受付：平成 4 年 2 月 28 日 原稿採択 : 平成 4 年 4 月 13 日 別刷請求先 : 大原奎昊 干280 千葉市亥鼻 1-8-1 千葉大学医学部耳鼻咽喉科学教室
} 